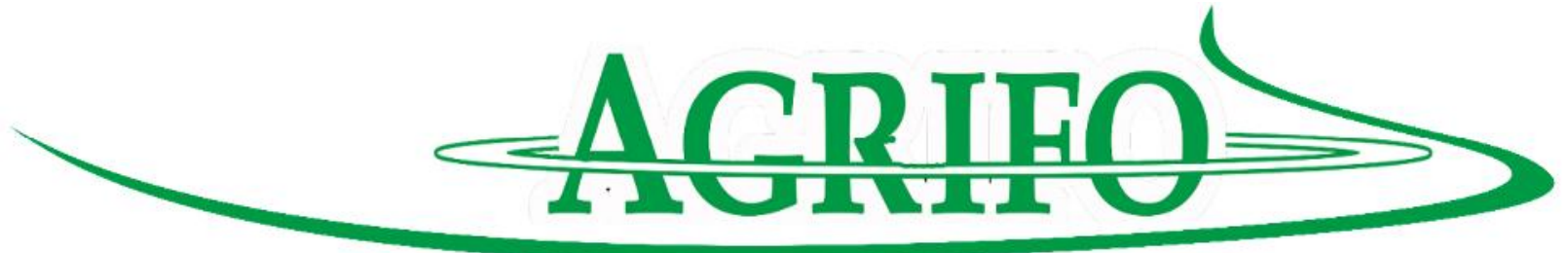

\title{
ANALISIS TATANIAGA IKAN BANDENG DI KECAMATAN SAMUDERA KABUPATEN ACEH UTARA
}

\author{
Muhammad Authar ND ${ }^{1}$, Rahmanta Ginting ${ }^{3}$, Luhut Sihombing ${ }^{3}$
}

Staff Pengajar Fakultas Pertanian, Universitas Malikussaleh, Aceh Utara Staff Pengajar Fakultas Pertanian Universitas Sumatera Utara

Email: authar_um@yahoo.com

\begin{abstract}
ABSTRAK
This research was conducted in September 2013. The purpose of this study was to analyze the magnitude of the marketing margin and share price received by farmers, and to analyze the ratio of benefit to cost. Data analysis method in this research is by using a business administration analysis to determine the share price, the marketing margin, share costs, share of profit between marketing institutions. To analyze the business administration, there are several approaches that can be used, namely by calculating the marketing margin, share price, share costs and benefits between marketing institutions.

Research results show that the marketing margin on each existing marketing channels are varied in magnitude and distribution is uneven. Based on analysis of business administration is known that the marketing margin on all marketing channels is varied in magnitude. In the first channel the marketing margin is $\mathrm{Rp}$ 5500, Rp 6000 in the second channel, Rp 4500 in the third channel, and Rp 5000 in the fourth channel. Share price received by the owner of the pond in the first channel is $74.72 \%, 72.73 \%$ in the second channel, $78.05 \%$ in the third channel, and $76.19 \%$ in the fourth channel. Ratio of profit to cost is also varied magnitude. In the first channel: ratio of profit to cost $(\mathrm{P} / \mathrm{C})$ was 0.18 for the owner of the pond, 1.08 for collecting traders of village, 1.08 for collecting traders of the district, 3.00 for collecting traders of regency, and 11.50 for retailers outside the area. In the second channel: ratio of profit to cost (P / C) was 0.18 for the owner of the pond, 1.08 for collecting traders of village, 1.34 for collecting traders of the district, 5.67 for collecting traders of regency, and 11.50 for retailers outside the area. In the third channel: ratio of profit to cost (P / C) was 0.18 for the owner of the pond, 1.34 for collecting traders of the district, 5.67 for collecting traders of regency, and 15.67 for retailers outside the area.
\end{abstract}

Keywords: Milkfish, Marketing Channel, Marketing Margin

\section{PENDAHULUAN}

$$
\text { Indonesia adalah negara }
$$

kepulauan yang terdiri dari sekitar

17.500 pulau. Panjang dari Sumatera sampai Papua kurang lebih 5000 km dengan total luas pulaunya 15 juta $\mathrm{Ha}$ yang terdiri dari 19,56\% daratan dan $80,44 \%$ lautan dan memiliki garis 
panjang pantai sekitar $81.000 \mathrm{~km}$. Jumlah penduduk Indonesia sekitar 60\%-nya hidup di pesisir pantai (Yasuko, 1999). Oleh sebab itu potensi perairan Indonesia yang besar ini sangatlah disayangkan jika tidak dimanfaatkan dengan baik.

\section{Berdasarkan jumlah} penduduk Indonesia yang mencapai 200 juta pada awal tahun 1997, diperlukan ikan sebanyak 3.840 .000 ton/tahun. Dikurangi ekspor ikan sekitar $17 \%$ produksi total maka jumlah ikan yang tersedia untuk pasar domestik hanya mencapai 3.574 .000 ton atau kurang 266.000 ton per tahun dari kebutuhan. Pada era perdagangan bebas yang dimulai tahun 2003 untuk AFTA dan tahun 2010 untuk APEC diperkirakan kesadaran masyarakat untuk mengkonsumsi lebih banyak protein akan meningkat sehingga bukan hal yang mustahil bila konsumsi ikan mencapai 25 $\mathrm{kg} / \mathrm{kapita} / \mathrm{tahun}$ seperti yang disyaratkan FAO. Pada tingkat konsumsi 25 kg/kapita, kebutuhan ikan pasar domestik dapat mencapai 6.000.000 ton/tahun, padahal paling tinggi (bila peningkatan produksi mencapai $6,22 \%$ per tahun) hanya dapat dipasok 5.361.000 ton/tahun. Dari aspek konsumsi, bandeng adalah sumber protein yang sehat sebab tidak mengandung kolesterol. Bandeng presto, bandeng asap, otak-otak adalah beberapa produk bandeng olahan yang dapat dijumpai dengan mudah di pasar (supermarket). Dalam sepuluh tahun terakhir ini permintaan bandeng meningkat rata-rata $6,33 \%$ pertahun, tetapi produksi hanya meningkat $\quad 3,82 \%$ pertahun (Anonymous, 2010).

Ikan bandeng (Chanos chanos) merupakan jenis ikan yang paling banyak dipelihara di tambak. Menurut hasil penelitian, produksi bandeng ditambak telah mencapai $2.000 \mathrm{~kg} / \mathrm{ha} /$ tahun. Sementara itu, perluasan areal usaha pertambakan juga telah bertambah banyak, baik di negeri sendiri maupuan negaranegara tetangga seperti Philipina dan Taiwan (Mudjiman, 2006).

Perbedaan tingkat produksi dalam suatu kegiatan usahatani tambak disebabkan oleh beberapa faktor, diantaranya pada penggunaan faktor input (modal, luas lahan, tenaga kerja, nener/gelondongan, 
pupuk, pestisida, pakan dan lain-lain) yang memadai dan juga kondisi alam yang sesuai. Selain itu, teknik

\section{2}

Salah satu aspek pemasaran yang diteliti dalam penelitian ini adalah mengidentifikasi penampilan pasar (market performance) pada pemasaran bandeng di kecamatan Samudera kabupaten Aceh Utara. Menurut Anindita (2003), penampilan pasar (market performance) merupakan salah satu aspek pemasaran yang penting dalam menilai seberapa baik aktivitas pemasaran memberikan kontribusi terhadap kesejahteraan petambak maupun pedagang. Market performance juga bisa menunjukkan seberapa baik sebuah proses pemasaran berjalan.

Berdasarkan permasalahan tersebut diatas maka penelitian ini bertujuan untuk mengetahui : (1) Besarnya marjin pemasaran dan share harga yang diterima petambak,(2) Besarnya rasio keuntungan dan biaya serta pengembalian modal antara lembaga pemasaran.

\section{METODE PENELITIAN}

Penelitian ini dilakukan di Kecamatan Samudera Kabupaten Aceh Utara pada sistem budidaya tradisional dan semi intensif. Pemilihan Lokasi 
dilakukan secara sengaja (purposive) dengan pertimbangan bahwa Kecamatan Samudera Penentuan lokasi ini dilakukan secara sengaja (purposive). Dipilihnya lokasi ini karena Kecamatan Samudera merupakan daerah penghasil bandeng ( Chanos chanos forskal ) terbesar nomor tiga di Kabupaten Aceh Utara Provinsi Aceh.

\section{Teknik Pengambilan Sampel}

Penentuan petambak
responden dilakukan secara acak
sederhana (simple random sampling)
di kecamatan Samudera dengan
kriteria sampel yaitu petambak yang
melakukan usaha budidaya Bandeng
yang luas tambaknya minimal $0,5 \mathrm{Ha}$.
Dari populasi petambak yang ada di
kecamatan Samudera sebanyak 130
orang diambil sampel sebanyak 50
persen yaitu sejumlah 65 orang
petambak. Menurut Parel et al. (1972) sebaiknya jumlah sampel tidak kurang dari 30 dan disesuaikan dengan kemampuan keuangan, keterbatasan tenaga dan waktu. Penentuan lembaga pemasaran dilakukan dengan cara snow ball sampling yaitu berdasarkan informasi dari petambak kepada siapa komoditas itu dijual.

\section{Teknik Pengumpulan Data}

Data yang dikumpulkan dalam penelitian ini adalah berupa data primer dan data sekunder. Data primer diperoleh dari petambak dan lembaga-lembaga pemasaran yang terlibat di dalam pemasaran ikan Bandeng. Data primer ini dikumpulkan melalui wawancara dengan menggunakan daftar pertanyaan untuk petambak dan lembaga pemasaran yang telah dipersiapkan sebelumnya. Data sekunder diperoleh dari data yang bersumber dari Dinas Perikanan Kabupaten Aceh Utara serta instansi lain yang terkait baik secara formal maupun informal.

\section{Analisis Data}

penelitian ini digunakan
analisis market performance
(penampilan pasar) untuk mengetahui
share harga, marjin pemasaran, share
biaya, share keuntungan dan tingkat
pengembalian atas modal antara
lembaga pemasaran. Untuk
menganalisis penampilan pasar ada
penelitian ini digunakan analisis market performance (penampilan pasar) untuk mengetahui share harga, marjin pemasaran, share biaya, share keuntungan dan tingkat lembaga pemasaran. Untuk menganalisis penampilan pasar ada 
beberapa pendekatan yang bisa digunakan yaitu dengan menghitung marjin pemasaran, share harga, share biaya dan keuntungan serta tingkat pengembalian modal antara lembaga pemasaran. Beberapa alat analisis yang bisa digunakan untuk melihat penampilan pasar adalah:

\section{a. Marjin Pemasaran}

$\mathrm{Mp}=\operatorname{Pr}-\mathrm{Pf}$

Atau

$$
\begin{aligned}
& \text { n n } \\
& \mathrm{Mp}=\sum_{\mathrm{i}=1}^{\mathrm{Bpi}}+\sum_{\mathrm{i}=1}^{\mathrm{Kpi}} \\
& \text { Bpi }=\sum \begin{array}{c}
\mathrm{n} \\
\mathrm{bij}
\end{array} \\
& \mathrm{i}=1 \\
& \mathrm{Kpi}=\mathrm{Pij}-\mathrm{Pbi}-\sum \mathrm{bij}
\end{aligned}
$$$$
\text { Dimana }
$$$$
\mathrm{Mp} \quad=\text { Marjin pemasaran }(\mathrm{Rp} / \mathrm{kg})
$$$$
\operatorname{Pr} \quad=\text { Harga eceran pada }
$$$$
\text { konsumen }(\mathrm{Rp} / \mathrm{kg})
$$$$
\text { Pf } \quad=\text { Harga pada petani produsen }
$$$$
\text { (Rp/kg) }
$$$$
\text { Bpi = Biaya lembaga pemasaran }
$$$$
\text { ke-i (Rp/kg) }
$$$$
\text { Kpi = Keuntungan pemasaran ke }
$$$$
\text { i }(\mathrm{Rp} / \mathrm{kg})
$$$$
\text { Pij = Harga jual lembaga }
$$$$
\text { pemasaran ke-i ( } \mathrm{Rp} / \mathrm{kg})
$$$$
\mathrm{Pbi}=\text { Harga beli lembaga }
$$
pemasaran ke-i $(\mathrm{Rp} / \mathrm{kg})$
Bij = Biaya pemasaran lembaga pemasaran ke-I dari berbagai jenis biaya mulai $\mathrm{j}=1$ sampai $\mathrm{j}=\mathrm{n}(\mathrm{Rp} / \mathrm{kg})$

\section{b. Share Harga yang Diterima} Petambak

SPf $=\frac{\operatorname{Pf}}{\operatorname{Pr}} \times \quad 100 \%$

Keterangan :

$\mathrm{SPf}=$ Share harga di tingkat petambak

$\mathrm{Pf}=$ Harga di tingkat petambak

$\operatorname{Pr}=$ Harga di tingkat konsumen

\section{c. Rasio Share Keuntungan dan Share Biaya Pemasaran}

$\mathrm{SKi}=(\mathrm{Ki}) /(\mathrm{Pr}-\mathrm{Pf}) \times 100 \%$

$\mathrm{SBi}=(\mathrm{Bi}) /(\mathrm{Pr}-\mathrm{Pf}) \times 100 \%$

$\mathrm{R}(\mathrm{Ki} / \mathrm{Bi})=\mathrm{SKi} / \mathrm{SBi}$

Dimana :

Ski $=$ Share keuntungan lembaga pemasaran ke-i

$\mathrm{SBi}=$ Share biaya pemasaran ke- $\mathrm{i}$ $\mathrm{R}(\mathrm{Ki} / \mathrm{Bi})=$ Rasio share keuntungan dan biaya pemasaran

\section{HASIL DAN PEMBAHASAN}

\section{Karakteristik Budidaya Bandeng}

Bandeng termasuk ikan pemakan tumbuhan (herbivora), dapat hidup di air tawar, air payau dan 
air laut. Karena benihnya berasal dari laut, maka ikan ini banyak dipelihara di air tambak-tambak air payau di sepanjang pantai utara Pulau Jawa, Sumatera, dan Sulawesi. Benih bandeng yang masih kecil dan halus disebut nener. Pada umur sekitar dua minggu, panjang nener hanya 11-13 $\mathrm{mm}$ dan beratnya $0,01 \mathrm{~kg}$. Bandeng dapat tumbuh dengan baik di daerah pantai yang landau, berarus tenang dan berair jenih.

Di Kecamatan Samudera, nener yang ditebar di tambak adalah nener berukuran seperti satu batang korek api, maka nener telah siap ditebar di tambak. Sebelum penebaran nener, tambak perlu dikeringkan dan diangkat lumpurnya. Setelah dilakukan pengurasan, tanggul ditinggikan dan pintu air dibuka.

Pada pintu air, dipasang semacam saringan yang bentuknya seperti jarring untuk menghindari sampah masuk ke dalam tambak. Di belakang jarring dipasang pompa air, agar air cepat masuk ke dalam tambak. Setelah tinggi air mencapai \pm $25 \mathrm{~cm}$, barulah dimasukkan nener, pada ketinggian air $25 \mathrm{~cm}$, sinar matahari masih bias masuk hingga ke dasar sehingga kondisi dasar tambak masih hangat sampai benih umur 2 bulan, belum diberikan pakan tambahan. Jadi benih masih makan pakan alami yang ada di tambak. Baru setelah umur benih lebih dari 2 bulan diberikan pakan buatan. Umur 5 bulan -6 bulan, jika pertumbuhannya baik, bandeng sudah siap dipanen.

\section{Saluran Pemasaran}

Ada beberapa lembaga pemasaran yang terlibat dalam pemasaran bandeng dari pantai tambak di Kecamatan Samudera hingga ke tangan konsumen. Lembaga pemasaran tersebut adalah pedagang pengumpul desa, pedagang pengumpul kecamatan, pedagang pengumpul kabupaten dan pedagang pengecer lokal maupun luar daerah. Pada umumnya pedagang pengumpul ini sudah mempuyai langganan. Mereka dating ke tambak bandeng pada saat musimh panen tiba. Mereka datang ke tambak pada sore hari antara pukul 15.00 sampai 17.00 WIB.kemudian hasil panen bandeng langsung ditimbang dan diangkat dan 
diangut dengan alat transportasi (pick up atau truck) yang dibawa oleh pedagang pengumpul.

\section{6}

Untuk melihat lebih jelasnya saluran pemasaran dan lembaga pemasaran yang terlibat dalam pemasaran bandeng di kecamatan Samudera dapat dilihat pada gambar berikut ini:

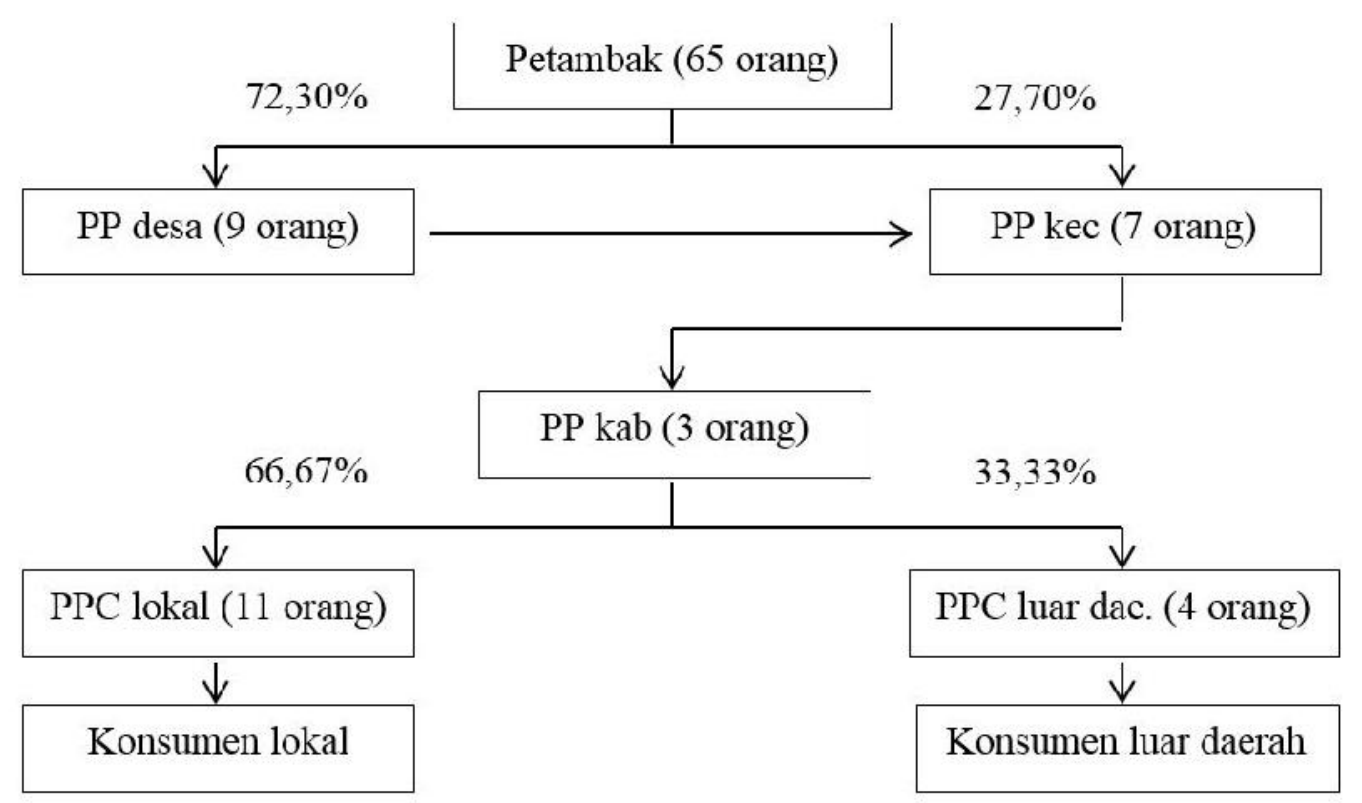

Gambar 1. Saluran pemasaran bandeng di kecamatan Samudera

Keterangan:

PP Desa = pedagang

pengumpul desa

$\mathrm{PP} \mathrm{Kec} \mathrm{=} \mathrm{pedagang}$

pengumpul kecamatan

$\mathrm{PP} \mathrm{Kab}=$ pedagang

pengumpul kabupaten

PPC Lokal = pedagang

pengecer lokal

PPC luar daerah $\quad=\quad$ pedagang

pengecer luar daerah

Dari gambar diatas dapat dilihat

bahwa pemasaran bandeng di kecamatan Samudera mempunyai 4 (empat) saluran pemasaran yaitu sebagai berikut:

\section{Saluran I}

Petani tambak - pedagang
pengumpul desa - pedagang
pengumpul kecamatan - pedagang
pengumpul kabupaten - pedagang
pengecer lokal.

\section{Saluran II}

Petani tambak - pedagang pengumpul desa - pedagang pengumpul 
kecamatan - pedagang pengumpul kabupaten - pedagang pengecer luar daerah.

\section{Saluran III}

Petani tambak - pedagang pengumpul kecamatan - pedagang pengumpul kabupaten - pedagang pengecer lokal.

\section{Saluran IV}

Petani tambak - pedagang pengumpul kecamatan - pedagang pengumpul kabupaten - pedagang pengecer luar daerah.

Dari data hasil penelitian dapat dijelaskan bahwa 65 orang petani tambak responden, 47 orang $(72,30 \%)$ menjual hasil panen bandengnya ke pedagang pengumpul desa dan 18 orang sisanya $(27,70 \%)$ menjual langsung ke pedagang pengumpul kecamatan. Pedagang pengumpul kecamatan seluruhnya ada 7 orang menjual bandengnya ke pedagang pengumpul kabupaten. Kemudian 3 orang $\quad(66,67 \%)$ pedagang pengumpul kabupaten menjualnya ke pedagang pengecer lokal dan 1 orang $(33,37 \%)$ menjualnya ke pedagang pengecer luar daerah.

Panjangnya saluran pemasaran menyebabkan share harga yang diterima petani tambak akan semakin kecil. Hal ini dipengaruhi oleh biaya pemasaran yang dikeluarkan oleh lembaga pemasaran yang terlibat sebagai akibat aktivitas pemasaran yang dilakukannya. Harga bandeng pada sata penelitian di tingkat petani tambak adalah Rp. 16.000 per kg,-Harga tersebut sama karena penelitian dilakukan pada satu kecamatan.

Panjangnya saluran pemasaran menyebabkan share harga yang diterima petani tambak akan semakin kecil. Hal ini dipengaruhi oleh biaya pemasaran yang dikeluarkan oleh lembaga pemasaran yang terlibat sebagai akibat aktivitas pemasaran yang dilakukannya. Harga bandeng pada sata penelitian di tingkat petani tambak adalah Rp. 16.000 per kg,-. Harga tersebut sama karena penelitian dilakukan pada satu kecamatan. Harga pada tingkat konsumen lokal berada pada kisaran Rp 20.500,sampai Rp 21.500,- per kilogram. Sedangkan pada tingkat konsumen 
luar daerah harganya Rp 21.000,-

sampai dengan $\mathrm{Rp} 22.000,-$ per

kilogram

\section{8}

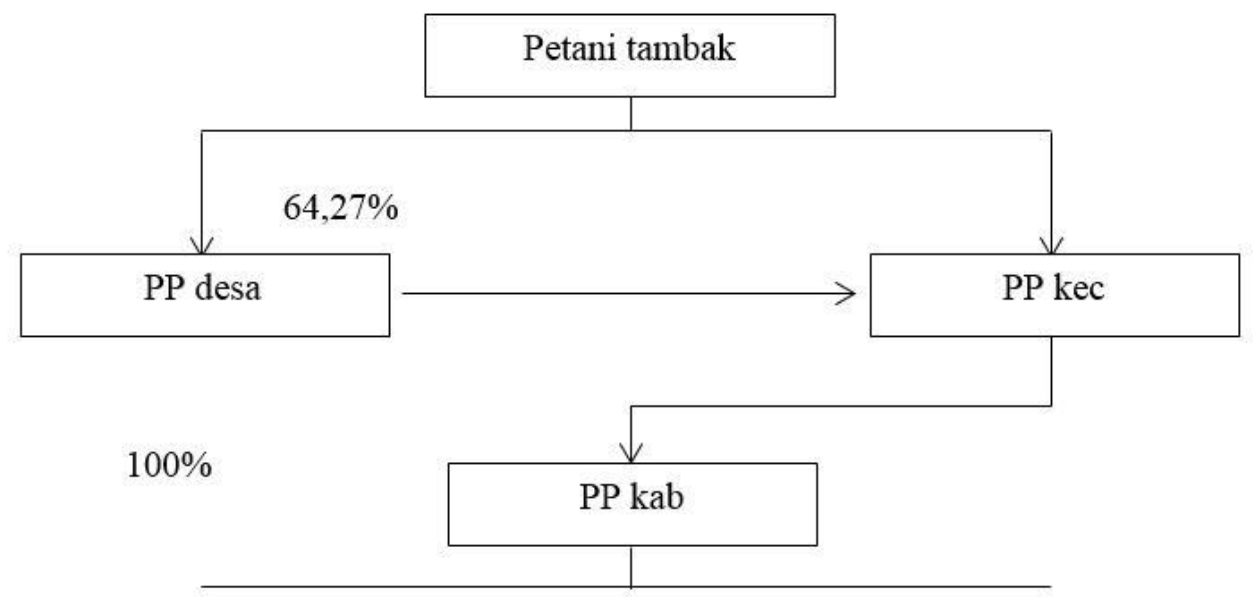

$22,280 \%$

PPC lokal

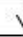

Konsumen lokal

Dari data hasil penelitian, produksi bandeng yang dihasilkan oleh petani tambak yang berjumlah 65 orang adalah sebanyak $39.000 \mathrm{~kg}$ (100\%). Dari jumlah tersebut yang dibeli oleh pedagang pengumpul desa sebanyak $28.197 \mathrm{~kg}(64,27 \%)$ dan yang dibeli pedagang pengumpul kecamatan 13934,7 $\mathrm{kg}$ (35,73\%). Kemudian dari pedagang pengumpul desa semuanya (100\%) dijual ke pedagang pengumpul kecamatan kemudian pedagang pengumpul kecamatan menjual semuanya (100\%)

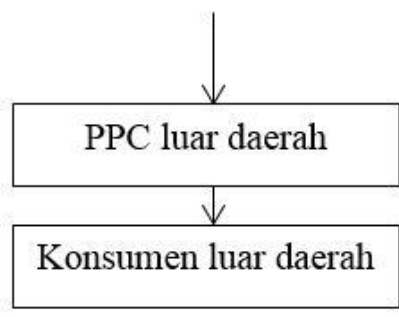

ke pedagang pengumpul kabupaten. Selanjutnya pedagang pengumpul kabupaten menjual sebanyak 8689,2 $\mathrm{kg}(22,28 \%)$ ke pedagang pengecer lokal dan menjual ke pedagang pengecer luar daerah sebanyak $30310,8 \mathrm{~kg}(77,72 \%)$.

Bandeng dari kecamatan Samudera ini ternyata lebih banyak dijual ke luar daerah. Hal ini terjadi karena konsumsi ikan bandeng di Kabupaten Aceh Utara relatif masih rendah selain itu harga ikan ini jika 
dijual ke luar daerah lebih tinggi dan sarana serta prasarana transportasi ke luar daerah sudah bagus, sehingga pengumpul kabupaten lebih memilih menjualnya ke pengecer luar daerah.

\section{Analisis Penampilan Pasar}

Dalam penelitian ini untuk mengetahui penampilan pasar dalam pemasaran bandeng analisis penampilan pasar dengan menghitung marjin pemasaran, share harga, share biaya dan share keuntungan dari tiaptiap lembaga pemasaran.

\section{Marjin Pemasaran}

$$
\text { Marjin pemasaran dapat }
$$

didefinisikan sebagai perbedaan harga yang dibayarkan oleh konsumen dengan harga yang diterima produsen, dengan kata lain marjin pemasaran merupakan selisih harga di tingkat konsumen dengan harga di tingkat produsen. Besarnya marjin pemasaran pada berbagai saluran pemasaran dapat berbeda, karena tergantung pada pendeknya saluran pemasaran dan aktivitas pemasaran yang dilaksanakan serta keuntungan yang diharapkan oleh lembaga pemasaran yang terlihat dalam proses pemasaran. Pada tabel 1 berikut dapat dilihat hasil analisa marjin, distribusi marjin, share harga yang diterima petani serta rasio keuntungan dan biaya dalam pemasaran ikan bandeng. 
Tabel 1. Marjin pemasaran, Distribusi Marjin, Share Harga yang diterima petani tambak, serta Rasio Keuntungn dan biaya pada Saluran I dalam Pemasaran Bandeng di Kecamatan Samudra Kabupaten Aceh Utara tahun 2013

\begin{tabular}{|c|c|c|c|c|c|}
\hline Saluran & $\begin{array}{c}\text { Lembaga } \\
\text { Pemasaran }\end{array}$ & $\begin{array}{c}\text { Biaya dan } \\
\text { Harga } \\
\text { (Rp/kg) }\end{array}$ & $\begin{array}{c}\text { Distribusi } \\
\text { marjin } \\
(\%)\end{array}$ & $\begin{array}{c}\text { Share } \\
\text { harga } \\
(\%)\end{array}$ & $\begin{array}{l}\text { Rasio } \\
\text { (K/B) }\end{array}$ \\
\hline \multirow{24}{*}{ I } & Petani tambak & & & & \\
\hline & Biaya usaha tani & 14750 & & 74,42 & 0,08 \\
\hline & Harga jual & 16000 & & & \\
\hline & Keuntungan & 1250 & & & \\
\hline & PP desa & & & & \\
\hline & Biaya pemasaran & 720 & 13,09 & & 1,08 \\
\hline & Harga beli & 16000 & & & \\
\hline & Harga jual & 17500 & & & \\
\hline & Keuntungan & 780 & 14,18 & & \\
\hline & PP kec & & & & \\
\hline & $\overline{\text { Biaya pemasaran }}$ & 640 & 11,64 & & 1,34 \\
\hline & Harga beli & 17500 & & & \\
\hline & Harga jual & 19000 & & & \\
\hline & Keuntungan & 860 & 14,64 & & \\
\hline & PP kab & & & & \\
\hline & Biaya pemasaran & 250 & 4,55 & & 3,00 \\
\hline & Harga beli & 19000 & & & \\
\hline & Harga jual & 20000 & & & \\
\hline & Keuntungan & 750 & 13,64 & & \\
\hline & PPC lokal & & & & \\
\hline & Biaya pemasaran & 150 & 2,73 & & 5,67 \\
\hline & Harga beli & 20500 & & & \\
\hline & Harga jual & 21500 & & & \\
\hline & Keuntungan & 850 & 15,54 & & \\
\hline Marjin & 5500 & & & & \\
\hline
\end{tabular}

Dari tabel 7 dapat diketahui bahwa pada saluran pemasaran yang pertama, marjin pemasarannya sebesar Rp 5500,-. Dari besarnya marjin tersebut didistribusikan untuk pedagang pengumpul desa pada biaya sebesar 13,09 persen dan keuntungannya sebesar 14,18 persen. 
Sedangkan untuk pedagang menjadi lebih besar. Selain itu sortasi pengumpul kecamatan, pada biaya bandeng juga dilakukan oleh sebesar 11,64 persen dan pedagang pengumpul desa. Walaupun keuntungannya 14,64 persen. Untuk nampaknya keuntungan terbesar pedagang pengumpul kabupaten, diperoleh oleh pedagang pengumpul pada biaya sebesar 4,55 persen dan kecamatan namun jika terlihat dari keuntungannya 13,64 persen. rasio keuntungan dan biaya, maka Kemudian untuk pedagang pengecer nilai rasio terbesar diperoleh oleh lokal pada biaya sebesar 2,73 persen pedagang pengecer lokal karena biaya dan keuntungannya 15,54 persen. pemasaran yang dikeluarkannya Dengan demikian dapat diketahui paling kecil.

bahwa biaya pemasaran terbesar dikeluarkan oleh pedagang pengumpul desa karena mereka harus mengambil langsung bandeng dari tambak yang letaknya tersebar sehingga biaya transportasinya

Pada saluran kedua, marjin pemasaran, share harga, share biaya dan keuntungan dapat dilihat pada Tabel 2.

\section{1}


Tabel 2. Marjin pemasaran, Distribusi Marjin, Share Harga yang diterima petani tambak, serta Rasio Keuntungn dan biaya pada Saluran II dalam Pemasaran Bandeng di Kecamatan Samudra Kabupaten Aceh Utara tahun 2013

\begin{tabular}{|c|c|c|c|c|c|}
\hline Saluran & $\begin{array}{c}\text { Lembaga } \\
\text { Pemasaran }\end{array}$ & $\begin{array}{c}\text { Biaya dan } \\
\text { Harga } \\
(\mathrm{Rp} / \mathrm{kg})\end{array}$ & $\begin{array}{c}\text { Distribusi } \\
\text { marjin } \\
(\%)\end{array}$ & $\begin{array}{c}\text { Share } \\
\text { harga } \\
(\%)\end{array}$ & $\begin{array}{l}\text { Rasio } \\
(\mathrm{K} / \mathrm{B})\end{array}$ \\
\hline \multirow{24}{*}{ II } & Petambak & & & \multirow{4}{*}{72,73} & \multirow{4}{*}{0,18} \\
\hline & Biaya usaha tani & 14750 & & & \\
\hline & Harga jual & 16000 & & & \\
\hline & Keuntungan & 1250 & & & \\
\hline & \multicolumn{2}{|l|}{ PP desa } & \multirow{4}{*}{12,00} & & \multirow{5}{*}{1,08} \\
\hline & $\overline{\text { Biaya pemasaran }}$ & 720 & & & \\
\hline & Harga beli & 16000 & & & \\
\hline & Harga jual & 17500 & & & \\
\hline & Keuntungan & 780 & 13,00 & & \\
\hline & \multicolumn{2}{|l|}{ PP kec } & \multirow{4}{*}{10,67} & & \multirow{5}{*}{1,34} \\
\hline & Biaya pemasaran & 640 & & & \\
\hline & Harga beli & 17500 & & & \\
\hline & Harga jual & 19000 & & & \\
\hline & Keuntungan & 860 & \multicolumn{2}{|l|}{14,33} & \\
\hline & \multicolumn{2}{|l|}{ PP kab } & \multirow{3}{*}{4,92} & & \multirow{5}{*}{5,67} \\
\hline & $\overline{\text { Biaya pemasaran }}$ & 250 & & & \\
\hline & Harga beli & 19000 & & & \\
\hline & Harga jual & 20000 & \multirow{2}{*}{\multicolumn{2}{|c|}{21,25}} & \\
\hline & Keuntungan & 750 & & & \\
\hline & PPC luar daerah & & \multirow{4}{*}{2,00} & & \multirow{5}{*}{11,50} \\
\hline & Biaya pemasaran & 120 & & & \\
\hline & Harga beli & 20500 & & & \\
\hline & Harga jual & 22000 & & & \\
\hline & Keuntungan & 1380 & 23,00 & & \\
\hline Marjin & 6000 & & & & \\
\hline
\end{tabular}

Dari tabel 2 dapat diketahui bahwa pada saluran pemasaran yang kedua, marjin pemasarannya sebesar Rp 6.000,-. Dari besarnya marjin tersebut didistribusikan untuk pedagang pengumpul desa pada biaya sebesar 12,00 persen dan keuntungannya sebesar 13,00 persen. 
Sedangkan untuk pedagang tambak yang letaknya tersebar pengumpul kecamatan, pada biaya sehingga biaya transportasinya sebesar 10,67 persen dan menjadi lebih besar. Selain itu sortasi keuntungannya 14,33 persen. Untuk bandeng juga dilakukan oleh pedagang pengumpul kabupaten, pedagang pengumpul desa. pada biaya sebesar 4,92 persen dan Sedangkan keuntungan terbesar keuntungannya 21,25 persen. diperoleh oleh pedagang pengecer Kemudian untuk pedagang pengecer luar daerah karena tidak banyak lokal pada biaya sebesar 2,00 persen aktivitas pemasaran yang dan keuntungannya 23,00 persen. Dengan demikian dapat diketahui bahwa biaya pemasaran terbesar dikeluarkan oleh pedagang pengumpul desa karena mereka harus mengambil langsung bandeng dari dilakukannya.

Untuk saluran ketiga marjin pemasaran, share harga, share biaya dan keuntungan dapat dilihat pada Tabel 3 berikut ini: 
Tabel 3.Marjin pemasaran, Distribusi Marjin, Share Harga yang diterima petani tambak, serta Rasio KEuntungn dan biaya pada Saluran III dalam Pemasaran Bandeng di Kecamatan Samudra Kabupaten Aceh Utara tahun 2013

\begin{tabular}{|c|c|c|c|c|c|}
\hline Saluran & $\begin{array}{c}\text { Lembaga } \\
\text { Pemasaran }\end{array}$ & $\begin{array}{c}\text { Biaya dan } \\
\text { Harga } \\
(\mathbf{R p} / \mathrm{kg})\end{array}$ & $\begin{array}{c}\text { Distribusi } \\
\text { marjin } \\
(\%)\end{array}$ & $\begin{array}{c}\text { Share } \\
\text { harga } \\
(\%)\end{array}$ & $\begin{array}{l}\text { Rasio } \\
(\mathbf{K} / \mathbf{B})\end{array}$ \\
\hline \multirow{19}{*}{ III } & Petambak & & & \multirow{4}{*}{78,05} & \multirow{4}{*}{0,18} \\
\hline & Biaya usaha tani & 14750 & & & \\
\hline & Harga jual & 16000 & & & \\
\hline & Keuntungan & 980 & & & \\
\hline & \multicolumn{5}{|l|}{ PP kec } \\
\hline & $\overline{\text { Biaya pemasaran }}$ & 640 & 14,22 & & \multirow[t]{4}{*}{1,34} \\
\hline & Harga beli & 16000 & & & \\
\hline & Harga jual & 17500 & & & \\
\hline & Keuntungan & 860 & 19,11 & & \\
\hline & PP kab & 250 & 5,56 & & \multirow[t]{5}{*}{5,00} \\
\hline & Biaya pemasaran & 17500 & & & \\
\hline & Harga beli & 19000 & & & \\
\hline & Harga jual & 1250 & 27,78 & & \\
\hline & Keuntungan & & & & \\
\hline & PPC lokal & 150 & 3,33 & & \multirow[t]{5}{*}{9,00} \\
\hline & $\overline{\text { Biaya pemasaran }}$ & 19000 & & & \\
\hline & Harga beli & 20500 & & & \\
\hline & Harga jual & 1350 & 30,00 & & \\
\hline & Keuntungan & & & & \\
\hline Marjin & 4500 & & & & \\
\hline
\end{tabular}

Dari tabel 3 dapat diketahui bahwa pada saluran pemasaran yang ketiga, marjin pemasarannya sebesar Rp 4.500,-. Dari besarnya marjin tersebut didistribusikan untuk pedagang pengumpul kecamatan, pada biaya sebesar 14,22 persen dan keuntungannya 19,11 persen. Untuk pedagang pengumpul kabupaten, pada biaya sebesar 5,56 persen dan keuntungannya 27,78 persen. Kemudian untuk pedagang pengecer lokal pada biaya sebesar 3,33 persen dan keuntungannya 30,00 persen. 
Dengan demikian dapat diketahui bahwa biaya pemasaran terbesar dikeluarkan oleh pedagang pengumpul kecamatan karena mereka harus mengambil langsung bandeng dari tambak yang letaknya tersebar sehingga biaya transportasinya menjadi lebih besar. Selain itu sortasi bandeng juga dilakukan oleh pedagang pengumpul kecamatan.
Sedangkan keuntungan terbesar diperoleh oleh pedagang pengecer.

\section{Rasio Keuntungan dan Biaya}

Untuk mengetahui besarnya pemasaran pada masing-masing saluran pemasaran dapat dilihat pada Tabel 4 dibawah ini.

Tabel 4. Rasio keuntungan dan biaya pada masing-masing tingkat pasar di berbagai Saluran Pemasaran Bandeng di Kecamatan Samudera Kabupaten Aceh Utara

\begin{tabular}{lllllll}
\hline $\begin{array}{l}\text { Saluran } \\
\text { pemasaran }\end{array}$ & \multicolumn{2}{l}{ Tingkat Pasar } & & & & \\
\cline { 2 - 7 } & Petambak & $\begin{array}{l}\text { PP } \\
\text { desa }\end{array}$ & PP kec & PP kab & $\begin{array}{l}\text { PPC } \\
\text { lokal }\end{array}$ & $\begin{array}{l}\text { PPC luar } \\
\text { daerah }\end{array}$ \\
\hline I & 0,18 & 1,08 & 1,08 & 3,00 & 5,67 & - \\
II & 0,18 & 1,08 & 1,34 & 5,67 & - & 11,50 \\
III & 0,18 & - & 1,34 & 5,00 & 9,00 & - \\
IV & 0,18 & - & 1,34 & 5,67 & - & 15,67 \\
\hline
\end{tabular}

Pada tabel diatas dapat dilihat besarnya rasio keuntungan dan biaya yang cukup bervariasi pada masingmasing tingkat pasar di berbagai saluran pemasaran bandeng. Rasio keuntungan dan biaya yang ada di tingkat petambak adalah 0,18 dan ini sama pada semua saluran. Hal ini disebabkan karena penelitian ini hanya dilakukan pada satu kecamatan sehingga harga jual bandeng di tingkat petambak relatif sama. Rasio keuntungan dan biaya yang diperoleh petani adalah sebesar 0,18 artinya setiap pengeluaran biaya sebesar satu satuan maka akan diperoleh kentungan sebesar 0,18 satuan. Pada tingkat pedagang pengumpul desa rasio keunungan dan biayanya sama yaitu sebesar 1,08. Hal ini disebabkan karena pada saluran pertama dan kedua pedagang pengumpul desa langsung mengambil banding dari petambak sehingga biaya dan keuntungan yang diperoleh relatif sama. Pada penambahan biaya 
sebesar satu satuan maka pedagang pengumpul desa akan mendapatkan tambahan keuntungan sebesar 1,08 di

tingkat pedagang 1,08 artinya setiap penambahan biaya sebesar 1 satuan akan menjadi penambahan keuntungan saluran sebesar 1,08 satuan dan pada satu, pedagang pengumpul kecamatan mengambil bandeng dari pedagang pengumpul desa. Pada saluran kedua, ketiga dan keempat besarnya rasio keuntungan dan biaya sama yaitu 1,34. Hal ini terjadi karena pedagang pengumpul kecamatan mengambil bandeng langsung dari petambak. Rasio sebesar 1,34 artinya dengan menambah biaya sebesar satu satuan maka akan diperoleh tambahan keuntungan sebesar 1,34. Di tingkat pedagang pengumpul kabupaten, rasio terbesar terdapat pada saluran kedua dan keempat yaitu 5,67 kemudian diikuti pedagang pengumpul kabupaten pada saluran ketiga, dan terakhir yang pertama. Hal ini terjadi karena pedagang pengumpul kabupaten pada saluran kedua dan keempat biaya pemasarannya kecil hanya mengeluarkan biaya transportasi sehingga keuntungan meningkat yang menyebabkan rasio keuntungan terhadap biaya juga meningkat.

Demikian pula pada tingkat pedagang pengecer lokal, saluran ketiga lebih besar dari saluran pertama karena biaya transportasi yang dikeluarkannya lebih kecil. Pada tingkat pedagang pengecer luar daerah saluran keempat paling besar rasionya karena pada tingkat ini tidak banyak aktivitas pemasaran yang dilakukan dan tidak ada biaya transportasi. Karena pedagang pengumpul kabupatenlah yang mendatangi pedagang pengecer luar daerah di pasar ikan yang ada di luar daerah dan pedagang pengecer luar daerah ini langsung menjual bandengnya ke konsumen dengan harga yang lebih tinggi dibandingkan di tingkat lokal.

Dari semua saluran tersebut, dapat diketahui bahwa sistem pemasaran bandeng di kecamatan Samudera belum baik karena belum mampu menyampaikan hasil dari petani tambak produsen kepada konsumen dengan biaya yang murah dan belum mampu mengadakan 
pembagian yang adil dari keseluruhan harga yang dibayarkan konsumen terakhir kepada semua pihak yang terlibat dalam kegiatan pemasaran tersebut.

\section{KESIMPULAN DAN SARAN}

Kesimpulan

1. Marjin pemasaran pada tiap saluran pemasaran yang ada besarnya bervariasi dan distribusinya tidak merata. Menurut analisis tataniaga, maka diketahui bahwa marjin pemasaran pada semua saluran pemasaran besarnya bervariasi. Pada saluran pertama marjinnya sebesar Rp. 5500,-, saluran kedua Rp. 6000,-, saluran ketiga Rp 4500,- dan saluran keempat Rp 5000,-.Share harga yang diterima petambak pada saluran pertama adalah $74,72 \%$, saluran kedua $72,73 \%$, saluran ketiga $78,05 \%$ dan pada saluran keempat $76,19 \%$.

2. Rasio keuntungan dan biaya besarnya juga bervariasi. Pada saluran pertama: rasio (K/B) untuk petambak adalah 0,18 , pedagang pengumpul desa 1,08 , pedagang pengumpul kecamatan 1,08 , pedagang pengumpul kabupaten 3,00 dan pedagang pengecer lokal 5,67. Pada saluran kedua: rasio (K/B) untuk petambak 0,18 , pedagang pengumpul desa 1,08 , pedagang pengumpul kecamatan 1,34, pedagang pengumpul kabupaten 5,67 dan pedagang pengecer luar daerah 11,50. Pada saluran ketiga: rasio $(\mathrm{K} / \mathrm{B})$ untuk petambak 0,18 , pedagang pengumpul kecamatan 1,34, pedagang pengumpul kabupaten 5,00 dan pedagang pengecer lokal 9,00. Pada saluran keempat: rasio (K/B) untuk petambak 0,18 , pedagang pengumpul kecamatan 1,34, pedagang pengumpul kabupaten 5,67, pedagang pengecer luar daerah 15,67.

Dengan demikian berdasarkan hasil analisis tataniaga pemasaran ikan Bandeng, maka dapat dikatakan bahwa proses pemasaran bandeng di kecamatan Samudera Kabupaten Aceh Utara belum berjalan dengan baik dan belum efisien. Petani tambak masih menerima harga yang sama pada semua saluran pemasaran 
sehingga pendapatan petambak relatif masih rendah.

Saran

1. Untuk memperkecil marjin pemasaran serta agar share harga yang diterima petani tambak meningkat maka perlu diupayakan saluran pemasaran yang lebih pendek.

2. Perlu dilakukan kerjasama berbagai pihak baik pemerintah, petani tambak serta pedagang, agar sistem pemasaran bandeng di Kecamatan Samudera Kabupaten Aceh Utara lebih efisien sehingga pendapatan petani tambak bisa meningkat.

\section{DAFTAR PUSTAKA}

Anindita, Ratya. 2003. Dasar-dasar Pemasaran Hasil Pertanian. Fakultas Pertanian Universitas Brawijaya. Malang.

BPS. 2006. Kabupaten Aceh Utara Dalam Angkat Tahun 2006. Biro Pusat Statistik. Kabupaten Aceh Utara.

Dahl, D. C. and Hammand, J. W. 1977. Market and price analysis the Agricultural Industry Me Growhill book Company, New York.

Downey, W. D. dan Erickson, S. P. 1987. Manajemen Agribisnis, Edisi Kedua, Alih Bahasa
Rochidayat Ganda S. dan Alfonsus Sirait, Erlangga, Jakarta.

Kartono, G. 2004. Kontribusi Kakao terhadap Pendapatan Petani Lahan Kering. Balai Pengkajian Teknologi Pertanian (BPTP) Jawa Timur, Malang.

Kottler, Philip. 1986. Dasar-dasar Pemasaran, Alih Bahasa: Wilhelmus W. Bakowatun, Intermedia, Jakarta.

Kotler. 1997. Dasar-dasar Pemasaran. Kosasih Iskandar Syah, Jakarta.

Mosher A.T. 1978. Menggerakkan dan Membangun Pertanian. Yasaguna, Jakarta.

Mubyarto. 1982. Penghantar Eknomi Pertanian, LP3ES, Jakarta.

Nitisemito, Alex S. 1984. Marketing. Ghalia Indonesia, Bandung.

Panglaykim, T. Pawitra M. Huseini dan M. Witarsa. 1987. Marketing, Penerbit Karmika, Universitas Terbuka, Jakarta.

Parel, C. P. 1973. Sampling design and Procedures. A/D/C New York. USA.

Purcell, W. D. 1983. Agricultural Marketing : System, Coordination, Cash and Futures Prices. Virginia Poltechnic. Reston Publishing Compang, A. Prentice - Hall Company. Reston, Virginia. USA. 
Ratna Evy. 1997. Usaha Perikanan di Indonesia, Mutiara Sumber Widya, Jakarta. 